\section{Daily Light Integral Affects Flowering and Quality of Greenhouse-grown Achillea, Gaura, and Lavandula}

\author{
Beth A. Fausey, ${ }^{1}$ Royal D. Heins, ${ }^{2}$ and Arthur C. Cameron ${ }^{2}$ \\ Department of Horticulture, Michigan State University, East Lansing, MI 48824-1325
}

Additional index words. herbaceous perennial, light quantity, flower induction

Abstract. The growth and development of Achillea xmillefolium L. 'Red Velvet', Gaura lindheimeri Engelm. \& Gray 'Siskiyou Pink' and Lavandula angustifolia Mill. 'Hidcote Blue' were evaluated under average daily light integrals (DLIs) of 5 to $20 \mathrm{~mol} \cdot \mathrm{m}^{-2} \cdot \mathrm{d}^{-1}$. Plants were grown in a $22 \pm 2{ }^{\circ} \mathrm{C}$ glass greenhouse with a 16-h photoperiod under four light environments: $50 \%$ shading of ambient light plus $P P F$ of $100 \mu \mathrm{mol} \cdot \mathrm{m}^{-2} \cdot \mathrm{s}^{-1}(\mathrm{L1})$; ambient light plus $P P F$ of $20 \mu \mathrm{mol} \cdot \mathrm{m}^{-2} \cdot \mathrm{s}^{-1}(\mathrm{~L} 2)$; ambient light plus $P P F$ of $100 \mu \mathrm{mol} \cdot \mathrm{m}^{-2} \cdot \mathrm{s}^{-1}(\mathrm{L3})$; and ambient light plus $P P F$ of $150 \mu \mathrm{mol} \cdot \mathrm{m}^{-2} \cdot \mathrm{s}^{-1}$ (L4). Between 5 to $20 \mathrm{~mol} \cdot \mathrm{m}^{-2} \cdot \mathrm{d}^{-1}$, DLI did not limit flowering and had little effect on timing in these studies. Hence, the minimum DLI required for flowering of Achillea, Gaura and Lavandula must be $<5 \mathrm{~mol} \cdot \mathrm{m}^{-2} \cdot \mathrm{d}^{-1}$, the lowest light level tested. However, all species exhibited prostrate growth with weakened stems when grown at a DLI of about $10 \mathrm{~mol} \cdot \mathrm{m}^{-2} \cdot \mathrm{d}^{-1}$. Visual quality and shoot dry mass of Achillea, Gaura and Lavandula linearly increased as DLI increased from 5 to $20 \mathrm{~mol} \cdot \mathrm{m}^{-2} \cdot \mathrm{d}^{-1}$ and there was no evidence that these responses to light were beginning to decline. While $10 \mathrm{~mol} \cdot \mathrm{m}^{-2} \cdot \mathrm{d}^{-1}$ has been suggested as an adequate DLI, these results suggest that 15 to $20 \mathrm{~mol} \cdot \mathrm{m}^{-2} \cdot \mathrm{d}^{-1}$ should be considered a minimum for production of these herbaceous perennials when grown at about $22{ }^{\circ} \mathrm{C}$.

Greenhouse production of flowering herbaceous perennials has increased dramatically in the past decade. Though forcing schedules have been developed for a wide range of perennials (Heins et al., 1997), seasonal variations in light, day length and temperature provide challenges for consistent production of high quality crops. Northern growers have reported incomplete or delayed flowering of some perennials during winter production.

Daily light integral (DLI), the cumulative number of photosynthetically active photons (400 to $700 \mathrm{~nm}$ ) received in a $24-\mathrm{h}$ period, is a useful variable related to plant growth and flowering responses. In the northern United States, including Michigan (lat. $42^{\circ}$ to lat. $45^{\circ} \mathrm{N}$ ), ambient greenhouse DLI ranges from 2.5 to $10 \mathrm{~mol} \cdot \mathrm{m}^{-2} \cdot \mathrm{d}^{-1}$ from November to February (Korczynski et al., 2002). At higher latitudes in the U.K. and northern Europe, DLI during this same period could be lower. While DLI requirements vary considerably with species, it has been generalized that most perennials require 10 to $16 \mathrm{~mol} \cdot \mathrm{m}^{-2} \cdot \mathrm{d}^{-1}$ for minimum acceptable quality, though these recommendations are subjective and not based on specific data (Faust, 2003). The consequences of growing perennials at DLI below recommended levels are not well documented.

It is well known that photosynthesis increases asymptotically with instantaneous light and the response is species specific. In whole-plant

Received for publication 20 Jan. 2004. Accepted for publication 29 June 2004. We gratefully acknowledge the financial support of the Michigan State University Agricultural Experiment Station and funding received from greenhouse growers supportive of Michigan State University floricultural research.

${ }^{1}$ Graduate student.

${ }^{2}$ Professor.

(the relationship between DLI and mass (DM) is generally linear up to 20 to 30 $\mathrm{mol} \cdot \mathrm{m}^{-2} \cdot \mathrm{d}^{-1}$ or higher for a diverse group of plants such as chrysanthemum, corn, and cucumber (Warrington and Norton, 1991). Depending on species, increasing DLI also improves numerous plant quality characteristics such as lateral branching and flower number (Faust, 2003). The optimum DLI for sun species can be as high as $\geq 50 \mathrm{~mol} \cdot \mathrm{m}^{-2} \cdot \mathrm{d}^{-1}$, far exceeding levels that can be achieved in greenhouses (Warrington and Norton, 1991).

Minimum DLI requirements for flowering can be very low, and low DLI can cause incomplete or delayed flowering of some potted flowering crops. For instance, chrysanthemum 'Bright Golden Anne' (Karlsson et al., 1989b), geranium 'Red Elite' (White and Warrington, 1988), and african violet (Faust and Heins, 1994) required minimum DLIs of only 1.8 , 3.3 , and $2.0 \mathrm{~mol} \cdot \mathrm{m}^{-2} \cdot \mathrm{d}^{-1}$, respectively, to initiate flowering. In field studies, however, the grass Deschampsiaflexuosa (L.) Trin. did not flower at DLIs $<9 \mathrm{~mol} \cdot \mathrm{m}^{-2} \cdot \mathrm{d}^{-1}$ (Foggo and Warrington, 1989). Warner and Erwin (2003) studied several Hibiscus species and found that most flowered even at the lowest light levels tested $\left(<5 \mathrm{~mol} \cdot \mathrm{m}^{-2} \cdot \mathrm{d}^{-1}\right)$. However, the herbaceous perennial Hibiscus moscheutos 'Disco Belle' required at least $14 \mathrm{~mol} \cdot \mathrm{m}^{-2} \cdot \mathrm{d}^{-1}$ to consistently flower (Warner and Erwin, 2003).

The objective of this study was to characterize growth and flowering responses of select herbaceous perennial species to a range of DLIs using existing greenhouse production protocols. We selected three common species known to be sun-loving plants in the garden: Achillea millefolium 'Red Velvet', Gaura lindheimeri 'Siskiyou Pink', and Lavandula angustifolia 'Hidcote Blue'. Specifically, we quantified plant responses to DLI between 5 to $20 \mathrm{~mol} \cdot \mathrm{m}^{-2} \cdot \mathrm{d}^{-1}$, expected levels under greenhouse conditions but well below expected optima for sun plants.

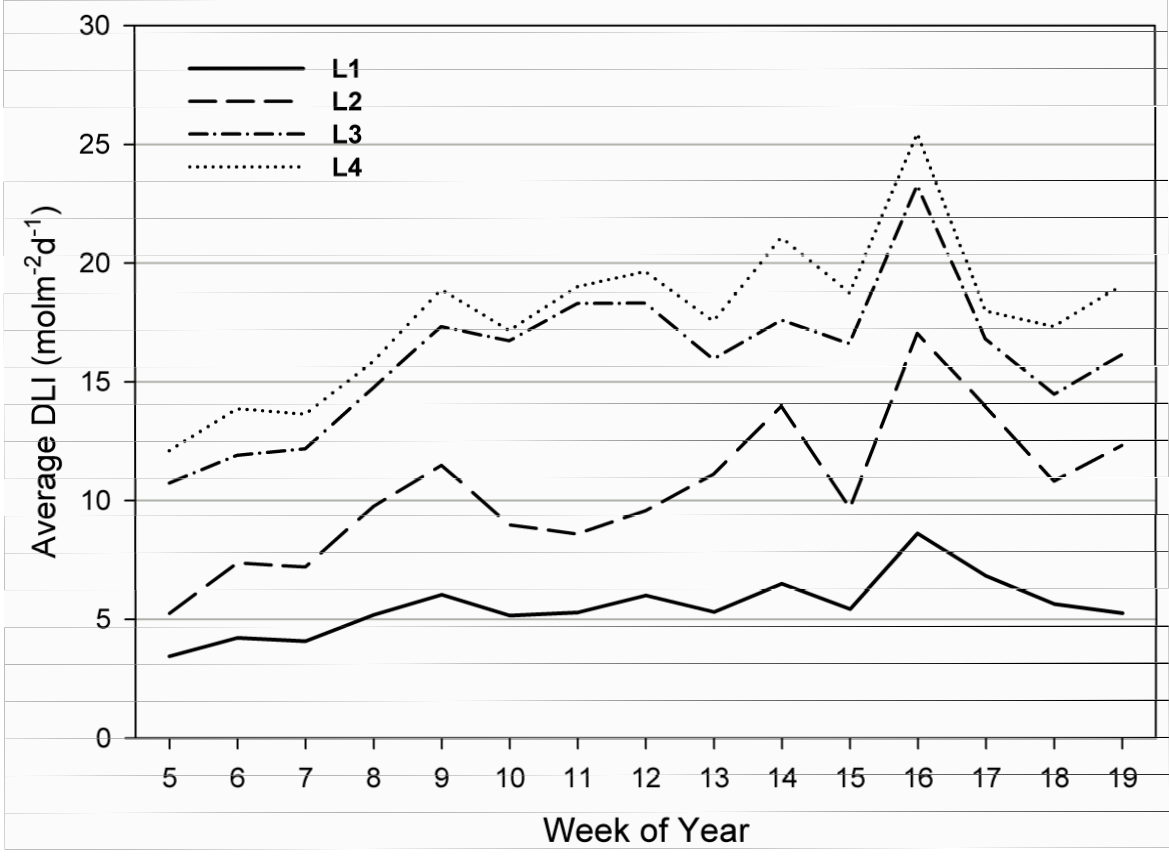

Fig. 1. Levels for each lighting treatment from 29 Jan to 4 June 2001. The light treatments were $50 \%$ shading of ambient light plus $P P F$ of $100 \mu \mathrm{mol} \cdot \mathrm{m}^{-2} \cdot \mathrm{s}^{-1}$ (L1); ambient light plus $P P F$ of $20 \mu \mathrm{mol} \cdot \mathrm{m}^{-2} \cdot \mathrm{s}^{-1}$ (L2); ambient light plus $P P F$ of $100 \mu \mathrm{mol} \cdot \mathrm{m}^{-2} \cdot \mathrm{s}^{-1}$ (L3); and ambient light plus $P P F$ of $150 \mu \mathrm{mol} \cdot \mathrm{m}^{-2} \cdot \mathrm{s}^{-1}$ (L4). 
rooting hormone (Dip 'N Grow, Clackamas, Ore.) and placed in 72-cell plug trays (50-mL cell volume) filled with a commercial peatperlite media (Sure-Mix; Michigan Grower Products, Galesburg, Mich.). Cuttings were rooted for 3 weeks in a propagation house with air and media temperatures of 23 and $26^{\circ} \mathrm{C}$, respectively. Once rooted, 40 uniform plants were transplanted to $13-\mathrm{cm}(1.1-\mathrm{L})$ square containers filled with the above media.

Lavandula angustifolia 'Hidcote Blue' seedlings were received from a commercial plug producer on 22 Oct., 19 Nov., and 17 Dec. 2000. Seedlings were subsequently grown under natural photoperiods for 10 weeks until they averaged 11 to 14 nodes. To induce flowering, seedlings were then placed in a $5^{\circ} \mathrm{C}$ cooler for 9 weeks with $10 \mu \mathrm{mol} \cdot \mathrm{m}^{-2} \cdot \mathrm{s}^{-1}$ provided by cool white fluorescent lamps for $9 \mathrm{~h} \cdot \mathrm{d}^{-1}$. Following cold treatment, plants were transplanted as described for Achillea and Gaura.

Plants were fertilized at every irrigation with well water (EC of $0.70 \mathrm{mS} \cdot \mathrm{cm}^{-1}$ and 105 $\mathrm{mg} \mathrm{Ca}, 35 \mathrm{mg} \mathrm{Mg}$, and $85 \mathrm{mg} \mathrm{S} \cdot \mathrm{L}^{-1}$ ) acidified with $\mathrm{H}_{2} \mathrm{SO}_{4}$ to a titratable alkalinity of $130 \mathrm{mg}$ $\mathrm{CaCO}_{3} \cdot \mathrm{L}^{-1}$ and water soluble fertilizer providing $125 \mathrm{~N}-12 \mathrm{P}-125 \mathrm{~K}-13 \mathrm{Ca} \mathrm{mg} \cdot \mathrm{L}^{-1}(30 \%$ ammoniacal $\mathrm{N}$ ) plus $1.0 \mathrm{Fe}-0.5 \mathrm{Mn}-0.5 \mathrm{Zn}-$ $0.5 \mathrm{Cu}-0.1 \mathrm{~B}-0.1 \mathrm{Mo} \mathrm{mg} \cdot \mathrm{L}^{-1}$ (MSU Special; Greencare Fertilizers, Chicago, Ill.).

Environmental control. Plants were grown in a $22 \pm 2{ }^{\circ} \mathrm{C}$ glass greenhouse with a $16-\mathrm{h}$ photoperiod provided by $400-\mathrm{W}$ high-pressure sodium (HPS) lamps from 0600 to $0800 \mathrm{HR}$ and 1700 to $2200 \mathrm{HR}$ with varying $P P F$. Ten plants of each species were placed under each of four light environments: $50 \%$ shading of ambient light plus PPF of 100 $\mu \mathrm{mol} \cdot \mathrm{m}^{-2} \cdot \mathrm{s}^{-1}$ (L1); ambient light plus $P P F$ of $20 \mu \mathrm{mol} \cdot \mathrm{m}^{-2} \cdot \mathrm{s}^{-1}$ (L2); ambient light plus $P P F$ of $100 \mu \mathrm{mol} \cdot \mathrm{m}^{-2} \cdot \mathrm{s}^{-1}$ (L3); and ambient light plus $P P F$ of $150 \mu \mathrm{mol} \cdot \mathrm{m}^{-2} \cdot \mathrm{s}^{-1}$ (L4) (Fig. 1). Additional supplemental lighting from HPS lamps provided a $P P F$ of $100 \mu \mathrm{mol} \cdot \mathrm{m}^{-2} \cdot \mathrm{s}^{-1}$ for L1, L3 and L4 or $20 \mu \mathrm{mol} \cdot \mathrm{m}^{-2} \cdot \mathrm{s}^{-1}$ for L2 when the ambient greenhouse $P P F$ dropped below $200 \mu \mathrm{mol} \cdot \mathrm{m}^{-2} \cdot \mathrm{s}^{-1}$ from 0800 to 1700 HR; supplemental lighting ceased when the $P P F$ exceeded $400 \mu \mathrm{mol} \cdot \mathrm{m}^{-2} \cdot \mathrm{s}^{-1}$. When combined with the multiple forcing dates, these light treatments created 16 average DLIs for Achillea and 12 average DLIs for Gaura and Lavandula.

Instantaneous light in each treatment was measured at plant height with two quantum sensors (model LI-189; LI-COR, Lincoln, Nebr.) connected to a datalogger (CR10; Campbell Scientific, Logan, Utah). Greenhouse air temperatures were controlled by a climatecontrol computer (model CD750; Priva, De Lier, The Netherlands) and were monitored on each bench with 36-gauge (0.127-mmdiameter) type-E thermocouples connected to a CR10 datalogger. Temperature and light measurements were collected every $10 \mathrm{~s}$, and the hourly average was recorded. The average daily temperature and DLI from forcing to visible bud, to anthesis Table 1), from visible bud to anthesis, and from forcing to final plant quality and DM assessment (see below) were calculated for each species.
Data collection and analysis. The date of visible flower bud, date of anthesis, stem length at visible bud and anthesis, lateral inflorescence number at anthesis, and final node number below first open flower were measured. Time to visible bud, time to anthesis, and time from visible bud to anthesis were calculated and used in analyses. Flowering percentage was calculated as the number of flowering plants divided by the total number of plants in each treatment. Plant quality was assessed 8, 6, and 7 weeks after transplant for Achillea, Gaura, and Lavandula, respectively, using a numerical rating scale from 1 to 5 where $1=$ poor quality and $5=$ high quality (Table 2 ). Following quality assessment, the above-ground biomass of each plant was harvested and dried in a 60 ${ }^{\circ} \mathrm{C}$ forced-air oven for $6 \mathrm{~d}$ after which shoot DM was measured for each species.

Linear regression analysis was performed on treatment means using PROC REG procedures in SAS version 8.0 (SAS Institute, Cary, N.C.). Linear regression lines are presented only when the correlation was statistically significant. Calculated DLI levels from forcing to visible bud, to anthesis, from visible bud to anthesis, or to final plant quality assessment and harvest were used in regression analyses, depending on variable. Error bars represent $95 \%$ confidence intervals.

\section{Results}

Light levels. Average DLI ranged from 5 to $20 \mathrm{~mol} \cdot \mathrm{m}^{-2} \cdot \mathrm{d}^{-1}$ depending on the start date and treatment (Table 1). DLI generally increased from late January to mid-March and then was relatively stable until whitewash was applied in late April (Fig. 1). Average daily temperature rose by 1 to $2{ }^{\circ} \mathrm{C}$ during the course of the experiment (Table 1 ).

Flowering percentage. All but one Achillea and all Gaura plants flowered under DLI ranging from 5 to $20 \mathrm{~mol} \cdot \mathrm{m}^{-2} \cdot \mathrm{d}^{-1}$ (Table 1 ). Flowering percentage of Lavandula varied from 60 to $100 \%$ but did not correlate with DLI. Lavandula 'Hidcote Blue' is an open-pollinated cultivar and inherent variability of the seed-propagated starting material may have contributed to the lack of flowering uniformity.

Growth and development responses. At low DLI, each species exhibited prostrate growth

Table 1. Start date, flower percent, and average daily light integral (DLI) and air temperature from forcing to anthesis for Achillea millefolium 'Red Velvet', Gaura lindheimeri 'Siskiyou Pink, and Lavandula angustifolia 'Hidcote Blue' grown under DLI treatments: $50 \%$ shading of ambient light plus PPF of $100 \mu \mathrm{mol} \cdot \mathrm{m}^{-2} \cdot \mathrm{s}^{-1}$ (L1); ambient light plus $P P F$ of $20 \mu \mathrm{mol} \cdot \mathrm{m}^{-2} \cdot \mathrm{s}^{-1}$ (L2); ambient light plus $P P F$ of 100 $\mu \mathrm{mol} \cdot \mathrm{m}^{-2} \cdot \mathrm{s}^{-1}(\mathrm{~L} 3)$; and ambient light plus $P P F$ of $150 \mu \mathrm{mol} \cdot \mathrm{m}^{-2} \cdot \mathrm{s}^{-1}(\mathrm{~L} 4)$.

\begin{tabular}{|c|c|c|c|c|c|}
\hline Species & $\begin{array}{l}\text { Light } \\
\text { treament }\end{array}$ & $\begin{array}{l}\text { Start } \\
\text { date }\end{array}$ & $\begin{array}{c}\text { Flower } \\
(\%)\end{array}$ & $\begin{array}{c}\text { Avg } \\
\text { DLI } \\
\left(\mathrm{mol} \mathrm{m}^{-2} \mathrm{~d}^{-1}\right)\end{array}$ & $\begin{array}{c}\text { Avg } \\
\text { air temp } \\
\left({ }^{\circ} \mathrm{C}\right)\end{array}$ \\
\hline \multirow[t]{16}{*}{ Achillea 'Red Velvet' } & \multirow[t]{4}{*}{ L1 } & $1 / 29 / 01$ & 90 & 4.9 & 22.0 \\
\hline & & $2 / 19 / 01$ & 100 & 5.6 & 21.7 \\
\hline & & 3/05/01 & 100 & 6.2 & 22.9 \\
\hline & & $3 / 27 / 01$ & 100 & 6.5 & 23.6 \\
\hline & \multirow[t]{4}{*}{ L2 } & $1 / 29 / 01$ & 100 & 8.5 & 21.2 \\
\hline & & $2 / 19 / 01$ & 100 & 10.2 & 21.7 \\
\hline & & $3 / 05 / 01$ & 100 & 11.4 & 22.1 \\
\hline & & $3 / 27 / 01$ & 100 & 12.7 & 22.8 \\
\hline & \multirow[t]{4}{*}{ L3 } & $1 / 29 / 01$ & 100 & 15.2 & 21.8 \\
\hline & & $2 / 19 / 01$ & 100 & 17.1 & 22.1 \\
\hline & & $3 / 05 / 01$ & 100 & 18.1 & 22.5 \\
\hline & & $3 / 27 / 01$ & 100 & 18.3 & 23.1 \\
\hline & \multirow[t]{4}{*}{ L4 } & $1 / 29 / 01$ & 100 & 16.4 & 22.9 \\
\hline & & $2 / 19 / 01$ & 100 & 18.5 & 23.0 \\
\hline & & $3 / 05 / 01$ & 100 & 19.7 & 23.3 \\
\hline & & $3 / 27 / 01$ & 100 & 20.3 & 23.7 \\
\hline \multirow[t]{12}{*}{ Gaura 'Siskiyou Pink' } & \multirow[t]{3}{*}{ L1 } & 2/19/01 & 100 & 5.6 & 22.1 \\
\hline & & $3 / 05 / 01$ & 100 & 5.6 & 21.8 \\
\hline & & $3 / 20 / 01$ & 100 & 6.5 & 23.1 \\
\hline & \multirow[t]{3}{*}{ L2 } & 2/19/01 & 100 & 9.7 & 21.4 \\
\hline & & $3 / 05 / 01$ & 100 & 10.1 & 21.8 \\
\hline & & $3 / 20 / 01$ & 100 & 11.5 & 22.2 \\
\hline & \multirow[t]{3}{*}{ L3 } & $2 / 19 / 01$ & 100 & 17.5 & 22.0 \\
\hline & & $3 / 05 / 01$ & 100 & 17.6 & 22.1 \\
\hline & & $3 / 20 / 01$ & 100 & 17.5 & 22.4 \\
\hline & \multirow[t]{3}{*}{ L4 } & 2/19/01 & 100 & 18.4 & 23.0 \\
\hline & & $3 / 05 / 01$ & 100 & 19.1 & 23.2 \\
\hline & & $3 / 20 / 01$ & 100 & 19.5 & 23.0 \\
\hline \multirow[t]{12}{*}{ Lavandula 'Hidcote Blue' } & \multirow[t]{3}{*}{ L1 } & $3 / 05 / 01$ & 80 & 5.8 & 22.7 \\
\hline & & $4 / 02 / 01$ & 60 & 6.6 & 23.0 \\
\hline & & $5 / 02 / 01$ & 100 & 6.1 & 24.3 \\
\hline & \multirow[t]{3}{*}{ L2 } & $3 / 05 / 01$ & 89 & 10.3 & 21.9 \\
\hline & & $4 / 02 / 01$ & 75 & 12.7 & 23.0 \\
\hline & & $5 / 02 / 01$ & 100 & 12.6 & 23.4 \\
\hline & \multirow[t]{3}{*}{ L3 } & $3 / 05 / 01$ & 100 & 17.7 & 22.3 \\
\hline & & $4 / 02 / 01$ & 100 & 18 & 23.2 \\
\hline & & $5 / 02 / 01$ & 100 & 15.8 & 22.3 \\
\hline & \multirow[t]{3}{*}{ L4 } & $3 / 05 / 01$ & 100 & 19.2 & 23.2 \\
\hline & & $4 / 02 / 01$ & 78 & 20.2 & 23.8 \\
\hline & & $5 / 02 / 01$ & 100 & 18.6 & 23.1 \\
\hline
\end{tabular}




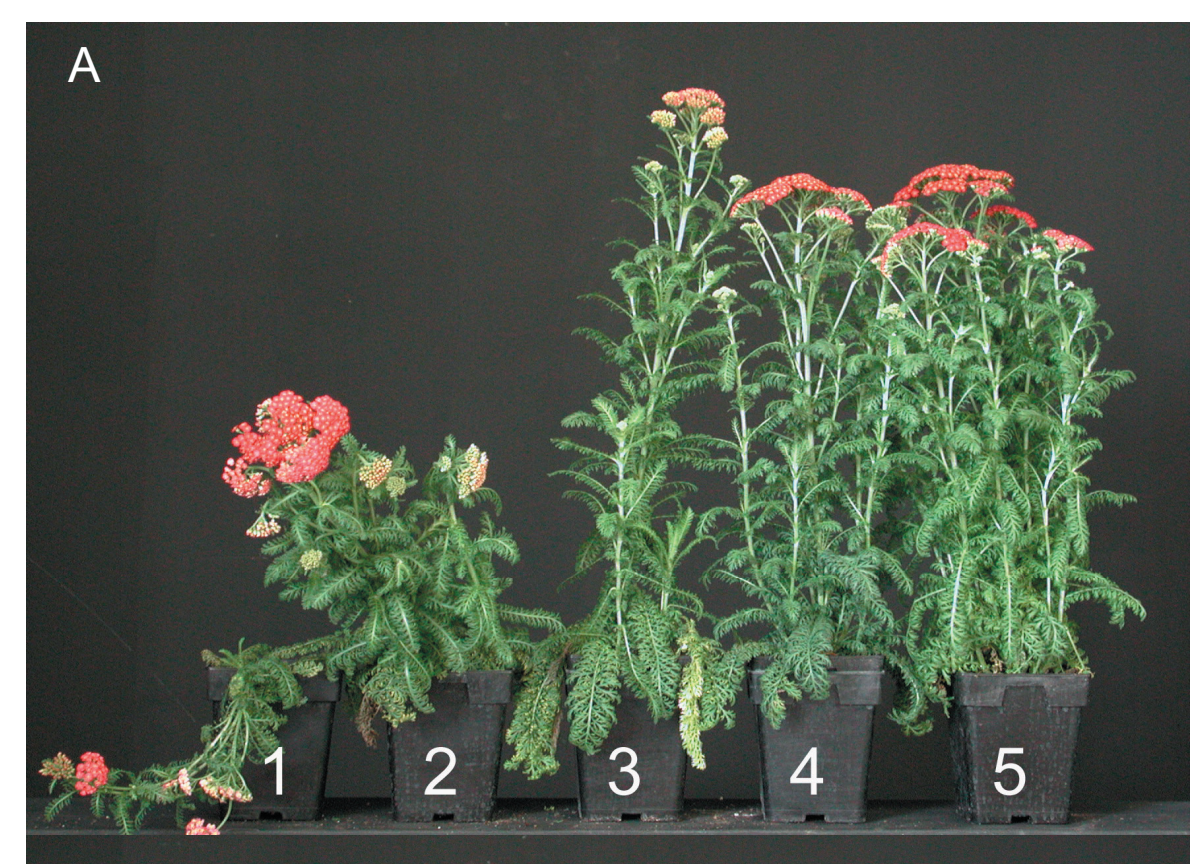

B

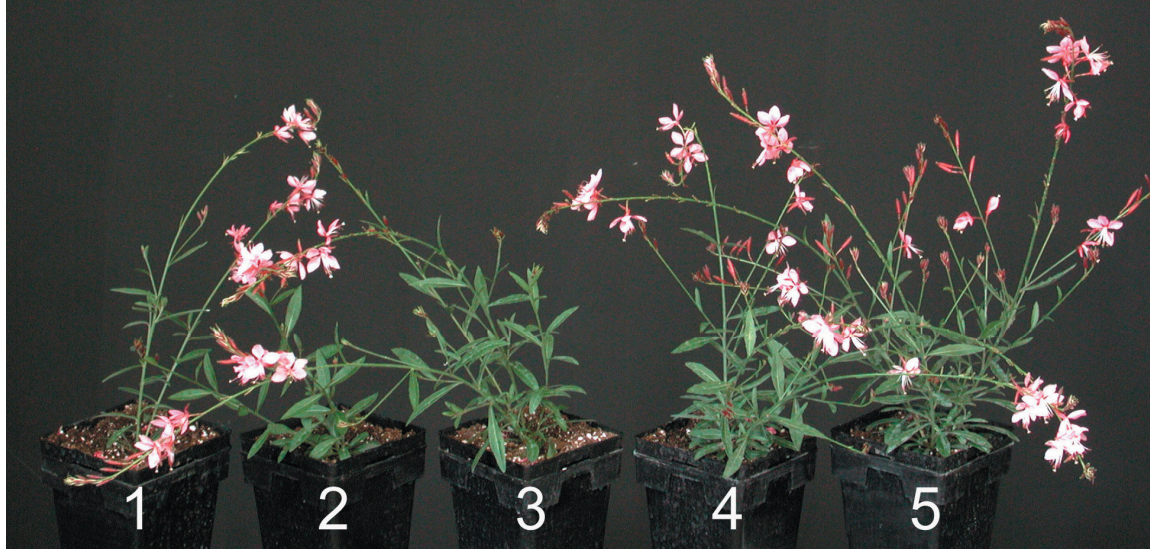

C

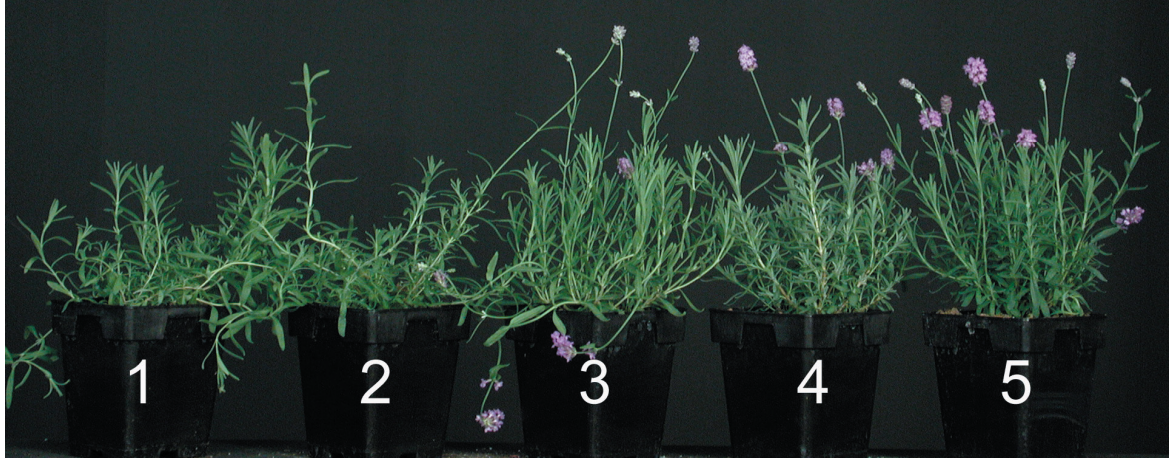

Fig. 2. Quality ratings for Achillea (A), Gaura (B), and Lavandula (C) as described in Table 2 after 8, 6, and 7 weeks of forcing, respectively. Numerical ratings were determined following the first forcing period for each species and were used to assess quality in subsequent forcing periods.

with weakened stems (Fig. 2A-C). As DLI increased above $10 \mathrm{~mol} \cdot \mathrm{m}^{-2} \cdot \mathrm{d}^{-1}$, stem strength, habit, lateral branching, and general appearance of all three species improved dramatically.
Achillea developed pink flowers that failed to deepen in color under low DLI. Basal shoot development (number and length) for Achillea was also reduced under low DLI. Lavandula grew asymmetrically and failed to develop gray foliage when grown with low DLI. A qualitative rating scale was developed based on these observed changes in growth and form (Table 2). Quality ratings of Achillea, Gaura, and Lavandula were linearly correlated with DLI from 5 to $20 \mathrm{~mol} \cdot \mathrm{m}^{-2} \cdot \mathrm{d}^{-1}$, though there was substantial variation (Fig. 3A-C).

Lateral inflorescence number increased linearly with DLI for Achillea and Gaura, while there was no significant correlation for Lavandula (Fig. 3D-F). As DLI increased from 5 to $20 \mathrm{~mol} \cdot \mathrm{m}^{-2} \cdot \mathrm{d}^{-1}$, inflorescence number of Gaura nearly tripled from 7 to 19 , and more than doubled for Achillea. Gaura flower number per inflorescence nearly doubled from about 25 to $\geq 40$ as DLI increased from 5 to 20 $\mathrm{mol} \cdot \mathrm{m}^{-2} \cdot \mathrm{d}^{-1}$ (data not shown).

Shoot DM accumulation of Achillea, Gaura, and Lavandula increased linearly with increasing DLI (Fig. 3G-I). DM increased 3-fold for Achillea, 3.4-fold for Gaura, and 2.6-fold for Lavandula as DLI increased from 5 to $20 \mathrm{~mol} \cdot \mathrm{m}^{-2} \cdot \mathrm{d}^{-1}$.

Achillea plants accumulated the most shoot biomass per unit of light received $(0.96$ $\mathrm{g} /$ plant/DLI in 8 weeks; Fig 3G), which infers that for each mol of light received above 5 $\mathrm{mol} \cdot \mathrm{m}^{-2} \cdot \mathrm{d}^{-1}$, Achillea gained nearly $1 \mathrm{~g} \mathrm{DM}$ per plant in 8 weeks. Gaura had a relatively small rate of increase in DM accumulation with increasing DLI ( $0.15 \mathrm{~g} / \mathrm{plant} / \mathrm{DLI}$ in 6 weeks $)$. Lavandula accumulated $0.28 \mathrm{~g} / \mathrm{plant} / \mathrm{DLI}$ in 7 weeks. When calculated over each forcing duration, DM increased $17.9 \mathrm{mg} /$ plant/DLI for Achillea (56 d), 2.9 for Gaura (42 d) and 5.7 for Lavandula (49 d) for plants grown with $>5 \mathrm{~mol} \cdot \mathrm{m}^{-2} \cdot \mathrm{d}^{-1}$.

Plants of all species had slightly shorter stems at visible bud with increasing DLI (Fig. $3 \mathrm{~J}-\mathrm{L})$. Stem length at visible bud decreased $24 \%$ (4.8 cm) for Achillea, $35 \%(2.4 \mathrm{~cm})$ for Gaura, and $35 \%(5.4 \mathrm{~cm})$ for Lavandula as DLI increased from 5 to $20 \mathrm{~mol} \cdot \mathrm{m}^{-2} \cdot \mathrm{d}^{-1}$. Stem length at first flower was not correlated with DLI for any of the three species (Fig. 3J-L), though actual plant height was reduced at low DLI since stems were prostrate and could not support their weight (Fig. 2A-C).

Flower timing. Flower timing of each species was either reduced or unaffected by increasing DLI. For Achillea, DLI reduced the time from forcing to visible bud and from forcing to anthesis, but not significantly from visible bud to anthesis (Fig. 4A, D, G). For Gaura, DLI reduced the time from forcing to visible bud, forcing from visible bud to anthesis, and from forcing to anthesis although absolute differences were only 3 to $5 \mathrm{~d}$ (Fig. $4 \mathrm{~B}, \mathrm{E}, \mathrm{H})$. Time from forcing to visible bud and anthesis did not vary significantly with DLI for Lavandula; however, time from visible bud to anthesis decreased, although minimally, by 1.5 d with increasing DLI (Fig. 4C, F, I).

\section{Discussion}

Gaura had the highest DLI requirement of the three species tested with only 8 of 120 plants attaining the highest quality rating. Gaura had to be grown with a DLI $\geq 18 \mathrm{~mol} \cdot \mathrm{m}^{-2} \cdot \mathrm{d}^{-1}$ 
Table 2. Visual quality characteristics and rating scale for assessment of Achillea 'Red Velvet', Gaura 'Siskiyou Pink', and Lavandula 'Hidcote Blue' plants grown under varying daily light integrals following 8,6 , and 7 weeks of forcing, respectively. Numerical rating scale: $1=$ poor quality to $5=$ high quality.

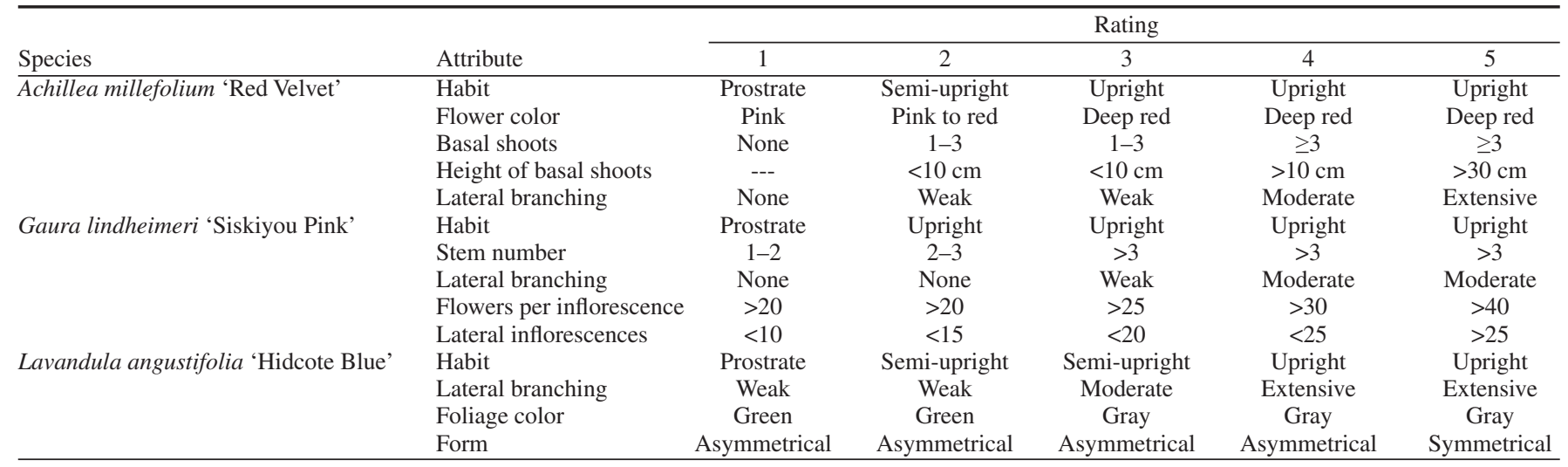

to consistently achieve a quality rating of 3 or greater, the minimum rating deemed acceptable for consumer sales. Gaura also had the lowest DMaccumulation though inflorescence and flower number increased substantially with increasing DLI. Gaura is native to the southwestern United States where ambient light levels may be 55 to $60 \mathrm{~mol} \cdot \mathrm{m}^{-2} \cdot \mathrm{d}^{-1}$ from May through July (Korczynski et al., 2002).

To consistently achieve quality ratings of 4 or greater, Achillea and Lavandula plants required DLI $\geq 20 \mathrm{~mol} \cdot \mathrm{m}^{-2} \cdot \mathrm{d}^{-1}$ (Fig. $3 \mathrm{~A}$ and C). Achillea and Lavandula are both native to Mediterranean regions with high light levels compared to the northern United States. Achieving DLI of $>20 \mathrm{~mol} \cdot \mathrm{m}^{-2} \cdot \mathrm{d}^{-1}$ for optimal production of these species in northern commercial greenhouses is challenging, particularly during the winter months.

Achillea plants accumulated the most shoot biomass per unit of light received (18 $\mathrm{mg} / \mathrm{plant} / \mathrm{DLI}$ ) and the response of all three species was essentially linear between 5 to 20 $\mathrm{mol} \cdot \mathrm{m}^{-2} \cdot \mathrm{d}^{-1}$. There was no evidence that the photosynthetic response had begun to level off at $20 \mathrm{~mol} \cdot \mathrm{m}^{-2} \cdot \mathrm{d}^{-1}$, implying that saturation occurs at even higher light levels. Warrington and Norton (1991) found that DM of corn (Zea mays L.) increased linearly by about $18.4 \mathrm{mg} / \mathrm{plant} / \mathrm{DLI}(29 \mathrm{~d})$ with increasing DLI from 11.3 to $73.5 \mathrm{~mol} \cdot \mathrm{m}^{-2} \cdot \mathrm{d}^{-1}$ while DM accumulation of cucumber, chrysanthemum, and radish were also linear in the range of DLIs ( 5 to $\left.20 \mathrm{~mol} \cdot \mathrm{m}^{-2} \cdot \mathrm{d}^{-1}\right)$ investigated in this study. DM of chrysanthemum 'Bright Golden Anne' grown at $20^{\circ} \mathrm{C}$ increased linearly and more than doubled as DLI increased from 5.8 to 22 $\mathrm{mol} \cdot \mathrm{m}^{-2} \cdot \mathrm{d}^{-1}$ (Karlsson and Heins, 1992).

With increasing DLI, Lavandula had a relatively low shoot DM accumulation (Fig. 3I) and no significant increase in inflorescence number (Fig. 3F), yet a marked increase in plant quality (Fig. 3C). The increase in quality was based more on stem strength, habit, form and foliage color than on DM or inflorescence number.

DLI did not limit flowering and had little effect on timing in these studies. Hence, the minimum DLI required for flowering of Achillea, Gaura and Lavandula must be $<5 \mathrm{~mol} \cdot \mathrm{m}^{-2} \cdot \mathrm{d}^{-1}$, the lowest light level tested. As DLI increased from 5 to $20 \mathrm{~mol} \cdot \mathrm{m}^{-2} \cdot \mathrm{d}^{-1}$, time to flower was accelerated only by about $5 \mathrm{~d}$ for Achillea, $7 \mathrm{~d}$ for Gaura and not significantly for Lavandula.
Node numberbelow the inflorescence correlated with DLI for Achillea $(p<0.0169$; $\mathrm{y}=-0.185 \mathrm{x}$ +17.79 ) but not for Gaura or Lavandula. This indicates that Achillea plants may have flowered earlier with increasing DLI due to irradiance effects on stage of development. It is likely that timing could be more affected as DLI drops below $5 \mathrm{~mol} \cdot \mathrm{m}^{-2} \cdot \mathrm{d}^{-1}$. For instance, decreasing DLI from 5.8 to $1.8 \mathrm{~mol} \cdot \mathrm{m}^{-2} \cdot \mathrm{d}^{-1}$ increased time to flower by $20 \mathrm{~d}$ for chrysanthemum 'Bright Golden Anne' grown at $20{ }^{\circ} \mathrm{C}$ (Karlsson et al., 1989a). Pearson et al. (1993) also noted a sharp decline in chrysanthemum floral development rate when grown at light levels below PAR radiation integral of $1 \mathrm{MJ} \cdot \mathrm{m}^{-2} \cdot \mathrm{d}^{-1}$ (about $\left.5 \mathrm{~mol} \cdot \mathrm{m}^{-2} \cdot \mathrm{d}^{-1}\right)$.
It is possible that the small decrease in flower timing observed in these studies may have resulted from associated increases in plant temperature with increasing DLI. Supplemental lighting with HPS lamps provides photosynthetic and nonphotosynthetic radiation energy that increases plant temperature and developmental rate thereby decreasing production time (Faust and Heins, 1997). Supplemental lighting at 50,75 , or $100 \mu \mathrm{mol} \cdot \mathrm{m}^{-2} \cdot \mathrm{s}^{-1}$ from HPS lamps increased vinca (Catharanthus roseus L.) plant temperature by $1.2,1.5$, and $1.7^{\circ} \mathrm{C}$, respectively, above air temperature (Faust and Heins, 1997). While plant temperature was not measured in this study, average differences in air temperature varied by about $2{ }^{\circ} \mathrm{C}$ between

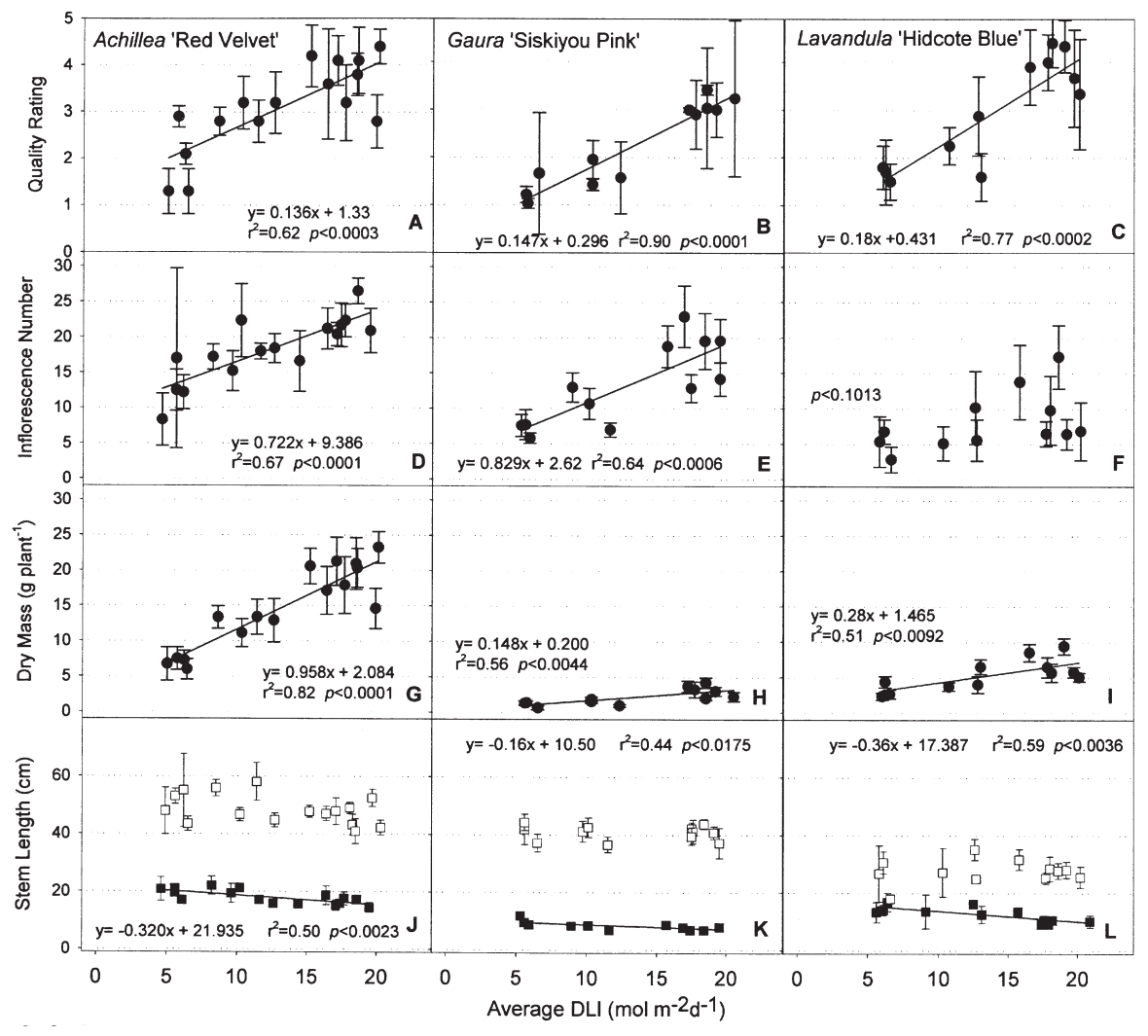

Fig. 3. Quality ratings, lateral inflorescence number at anthesis, dry weight accumulation, and stem length measured at visible bud (shaded squares) and anthesis (open squares) for Achillea millefolium 'Red Velvet', Gaura lindheimeri 'Siskiyou Pink', and Lavandula angustifolia 'Hidcote Blue' as a function of daily light integral. Regression lines are shown for significant correlations only. Error bars represnet 95\% intervals. Quality ratings and dry weight were determined for Achillea, Gaura, and Lavandula after 8,6 , and 7 weeks respectively. 


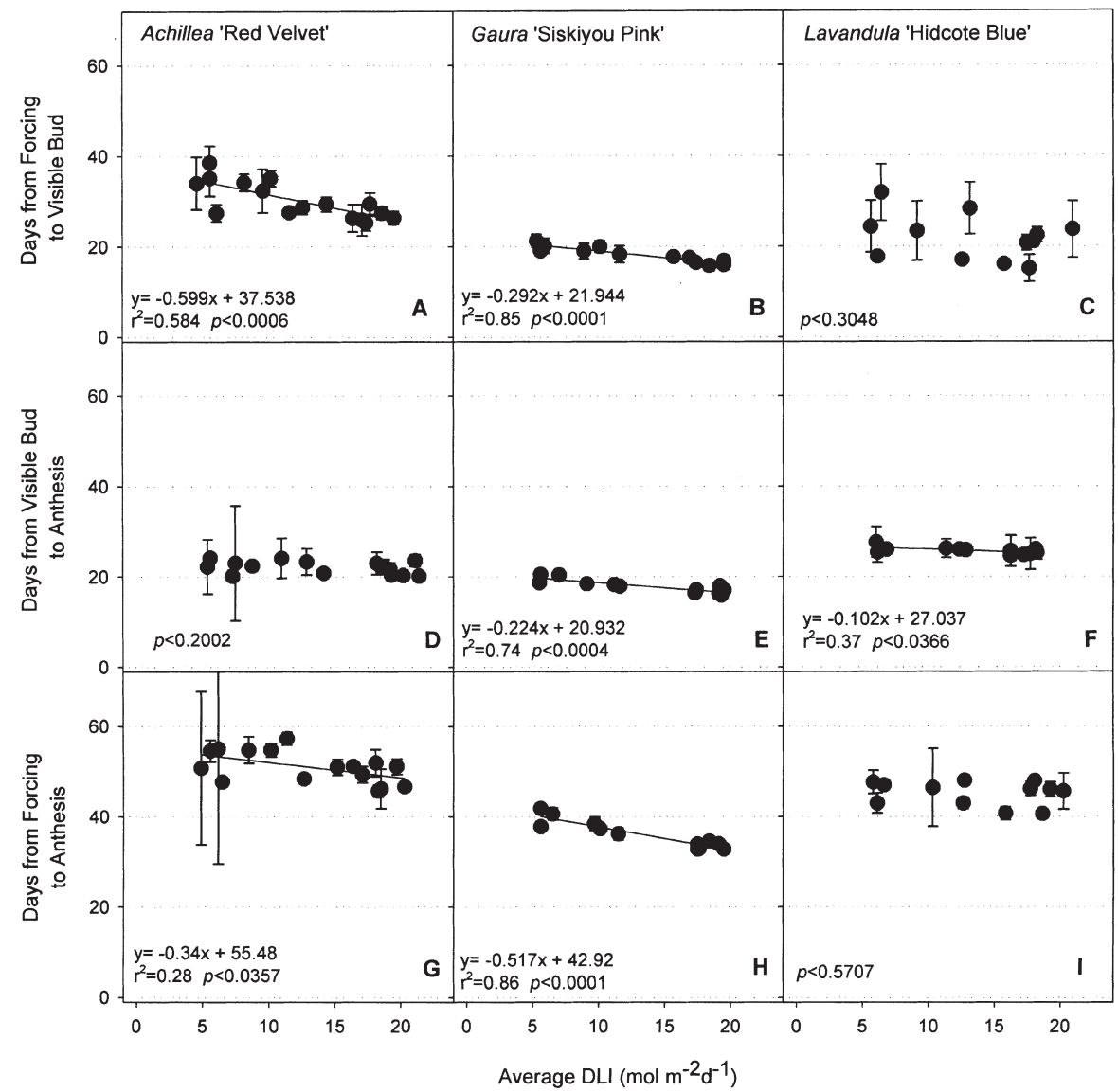

Fig. 4. Time from forcing to visible bud from forcing to anthesis for Achillea millefolium 'Red Velvet', Gaura lindheimeri 'Siskiyou Pink', and Lavandula angustifolia 'Hidcote Blue'. Regression lines are shown for significant correlations only. Error bars represnet $95 \%$ intervals.

the L2 lighting treatment compared with other lighting treatments using supplemental lighting (Table 1). While we presume plant meristem temperature may be greater under high DLI and with HPS lamps, time from visible bud to anthesis of Achillea was not affected by DLI and the time from visible bud to anthesis of Gaura and Lavandula was only affected slightly by 3 and $1.5 \mathrm{~d}$, respectively (Fig. 4D-F).

Linear increases in plant quality, DM accumulation, and inflorescence number with increasing DLI from 5 to $20 \mathrm{~mol} \cdot \mathrm{m}^{-2} \cdot \mathrm{d}^{-1}$ illustrate the impact of DLI on growth and flowering of herbaceous perennial species. Prostrate habit with reduced stem strength and lateral branching are indicative of plants receiving
Faust, J.E. and R.D. Heins. 1994. Modeling inflorescence development of the African violet (Saintpaulia ionantha Wendl.). J. Amer. Soc. Hort. Sci. 119(4):727-734.

Faust, J.E. and R.D. Heins. 1997. Quantifying the influence of high-pressure sodium lighting on shoot-tip temperature. Acta Hort. 418:85-91.

Foggo, M.N. and I.J. Warrington. 1989. The influence of photosynthetically active radiation and vernalization on flowering of Deschampsia flexuosa (L.) Trin. (Poaceae). Functional Ecol. 3(5):561-567.

Heins, R.D., A.C. Cameron, W.H. Carlson, E. Runkle, C. Whitman, M. Yuan, C. Hamaker, B. Engle, and P. Koreman. 1997. Controlled flowering of herbaceous perennials, p. 15-31. In: E. Goto et al. (eds.). Plant production in closed ecosystems. Kluwer Academic Publ., The Netherlands.

Karlsson M.G. and R.D. Heins. 1992. Chrysanthemum dry matter partitioning patterns along irradiance and temperature gradients. Can. J. Plant Sci. 72:307-316.

Karlsson, M.G., R.D. Heins, J.E. Erwin, R.D. Berghage, W.H. Carlson, and J.A. Biernbaum. 1989a. Irradiance and temperature effects on time of development and flower size in chrysanthemum. Scientia Hort. 39:257-267.

Karlsson, M.G., R.D. Heins, J.E. Erwin, R.D Berghage, W.H. Carlson, and J.A. Biernbaum. 1989b. Temperature and photosynthetic photon flux influence chrysanthemum shoot development and flower initiation under short-day conditions. J. Amer. Soc. Hort. Sci. 114(1):158-163.

Korczynski, P.C., J. Logan, and J.E. Faust. 2002. Mapping monthly distribution of daily light integrals across the contiguous United States. HortTechnology 12(1):12-16.

Niu, G., R.D. Heins, A.C. Cameron, and W.H Carlson. 2001. Day and night temperatures, daily light integral, and $\mathrm{CO}_{2}$ enrichment affect growth and flower development of Campanula carpatica 'Blue Clips'. Scientia Hort. 87:93-105.

Pearson, S., P. Hadley, and A.E. Wheldon. 1993. A reanalysis of the effects of temperature and irradiance on time to flowering in chrysanthemum (Dendranthema grandiflora). J. Hort. Sci. 68(1):89-97.

Warner, R.M. and J.E. Erwin. 2003. Effect of photoperiod and daily light integral on flowering of five Hibiscus sp. Scientia Hort. 97:341-351.

Warrington, I.J. and R.A. Norton. 1991. An evaluation of plant growth and development under various daily quantum integrals. J. Amer. Soc. Hort. Sci. 116(3):544-551.

White, J.W. and I.J. Warrington. 1988. Temperature and light integral effects on growth and flowering of hybrid geraniums. J. Amer. Soc. Hort. Sci. 113(3):354-359. 